NBER WORKING PAPER SERIES

\title{
THE CRISIS IN GERMANY'S PENSION INSURANCE SYSTEM AND HOW IT CAN BE RESOLVED
}

\author{
Hans-Werner Sinn \\ Working Paper 7304 \\ http://www.nber.org/papers/w7304 \\ NATIONAL BUREAU OF ECONOMIC RESEARCH \\ 1050 Massachusetts Avenue \\ Cambridge, MA 02138 \\ August 1999
}

The author wishes to thank Juli Irving-Lessmann, Marcel Thum, Jakob von Weizsäcker and Frank Westermann for careful research assistance and the members of the Council of advisors to the German Federal Ministry of Economics and Research for stimulating discussions. The paper has been developed from a lecture that was given to the annual assembly of the Bavarian Academy of Sciences in December 1998. The views expressed herein are those of the authors and not necessarily those of the National Bureau of Economic Research. 
(C) 1999 by Hans-Werner Sinn. All rights reserved. Short sections of text, not to exceed two paragraphs, may be quoted without explicit permission provided that full credit, including $\odot$ notice, is given to the source.

The Crisis of Germany's Pension Insurance

System and How It Can Be Resolved

Hans-Werner Sinn

NBER Working Paper No. 7304

August 1999

JEL No. H55

\section{$\underline{\text { ABSTRACT }}$}

The paper discusses the options for a reform of the German pension system using a model developed at CES for the German Council of economic advisors to the Federal Ministry of Economics and Research. It is argued that the German pay-as-you-go-system is efficient in a present value sense but will nevertheless need the support of a funded system to avoid a financial crisis. The paper investigates the possibility of introducing obligatory private savings at a variable rate where the time path of the savings rate is chosen so as to stabilize the sum of this rate and the pay-as-you-go contribution rate, given the time path of pensions as defined in the present system.

\section{Hans-Werner Sinn}

CESifo

Schackstr. 4

80539 Munich

Germany

and NBER

hans-werner.sinn@ces.vwl.uni-muenchen.de 


\section{Introduction}

I am concerned that "the feeling of human dignity, which I want even the poorest German to have, should be kept alive, that he should not simply be an object of charity without any rights, that he should have a peculium which belongs to him alone... which makes it easier for him to open many doors which otherwise would be closed, and which, if he can take his contribution out again when he leaves, ensures him better treatment in the house to which he has been admitted."1 These are the words Bismarck used in his speech to the Reichstag on 2nd April 1881 to justify his social legislation. It is significant that he used the word "peculium" for the public assistance he wanted the old and sick to receive. The peculium was the money Roman slaves were allowed to save up and could ultimately use to buy their freedom. Obviously, Bismarck saw the old people's situation as an underprivileged one, similar to that of the slaves in ancient Rome, and from which it was necessary to liberate them.

Bismarck did succeed in liberating pensioners. People in today's society are not stigmatized for being old and do not need to beg from their children to live a well ordered life. However now, a hundred years later, the pendulum has swung in the opposite direction. The real problem today is the enormous burden facing contributors, not the stigma facing pensioners. The combined rate of contributions by employers and employees to the pension insurance system in Germany is $20 \%$. This burden will become even heavier in future, because there will be more and more pensioners and fewer and fewer people available to work. Even today, many people are finding the contributions burden oppressive, and there are grounds for believing that this burden is one of the reasons for the high wage costs in Germany and for the resulting unemployment.

The paper discusses the impending problem of financing the German pension insurance system and the possibilities available for sensible reforms which can prevent the system breaking

\footnotetext{
${ }^{1}$ Cited according to Stein (no year).
} 
down under the weight of the excessive contributions and endangering Germany's political system. It reports on research carried out by Munich's Center for Economic Studies (CES) for the Scientific Advisory Council of the Federal Ministry of Economics and Research ${ }^{2}$.

\section{The Implications of the Demographic Developments for the Pension Insurance System}

There were no special financing problems when Bismarck introduced the pension insurance system because the number of old people affected was very small relative to the number of young people. Figure 1 compares the German age pyramid in Bismarck's time with that in 1995. It can be seen that the number of old people at the top of the pyramid in Bismarck's time was extremely small relative to the number of young people lower down. If birth rates had been constant, the pyramid would have looked the same in 1995 as it did in 1875 . However, this is not the case. Today's pyramid, which is shown on the right, belies its name. It should more correctly be called a pine tree, not a pyramid, as the younger age classes contain less people than the older ones.

\footnotetext{
${ }^{2}$ Wissenschaftlicher Beirat (1998). Cf. also Sinn (1997, 1998a, 1998b).
} 
Figure 1: The German age pyramid in Bismarck's time (1875) and today (1995)

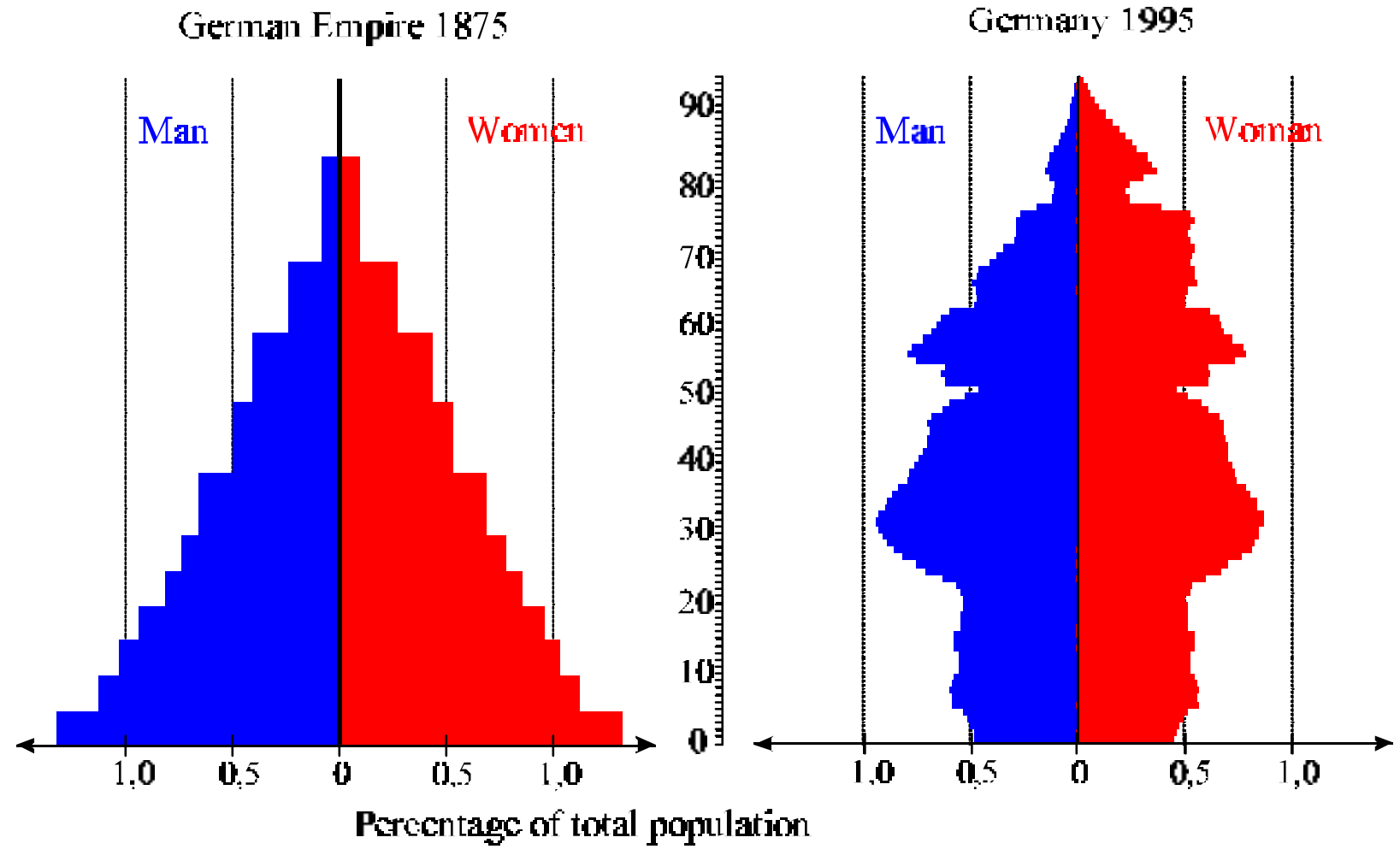

Sources: Statistisches Bundesamt, Statistisches Jahrbuch, Tab. 3.11, Bevölkerung 1995 nach dem Alter, p. 62, 1997; Kaiserliches Statisches Amt, Statistisches Jahrbuch für das Deutsches Reich, Vol. 30, April, pp. 7-9, tab.4. Die Bevölkerung am 1. Dez 1875 nach Geschlecht und 11 Altersklassen, 1878.

It is quite obvious that the pine tree structure creates problems for a pension insurance system which operates with pay-as-you-go financing. Fewer and fewer young people must finance more and more old people. It is also quite obvious that the greatest difficulties are yet to come. It will become really bad when the heavy branches now at the lower levels of the pine tree move up to the pensionable levels. This is what is going to happen in the thirties of the next century. By then it will hardly be possible to keep the pay-as-you-go process operating in its present form.

The pine tree got its shape because the growth rate of the German population has been falling continuously over time. Last century this growth rate was about $1.1 \%$ and, in Europe, it 
was the third highest after Great Britain and Finland. ${ }^{3}$ Today the growth rate is $-0.1 \%$ in terms of the native German population and $+0.6 \%$ when immigrants are included. ${ }^{4}$

The problem is that the Germans do not have as many children as they used to. Ten Germans now only have on average seven children. Germany is no longer third from the top in Europe; in the OECD it is now third from the bottom. Only Spain and Italy have still lower birth rates than Germany does.

The falling number of children is not the only thing that creates problems for the pension insurance system, increasing life expectancy does so, too. Medical advances are increasing remaining life expectancy of a sixty five year old German man or woman by around 1.5 months each year, that is, by an additional year every eight years. The gap between the number of births and remaining life expectancy is widening all the time and this will create more and more trouble for the pension insurance system because the number of people of pension age is rising continuously relative to those of working age.

\section{Implications for the Development of the Contribution Rate}

The demographic distortion has serious effects for the contribution rates of the pension insurance system. Currently 100 Germans in working age (between 20 and 64 years) support 25 older people. In 2035, they will have to support between 50 and 55 older people, depending on which population forecast is used. ${ }^{5}$ One does not need to set up a forecasting model to see that there will need to be either a very large increase in the contribution rate or a considerable reduction in the pension.

\footnotetext{
${ }^{3}$ See Mitchell (1981).

${ }^{4}$ See Statistisches Bundesamt, Statistisches Jahrbuch der BRD, various issues.

${ }^{5}$ See Statistisches Bundesamt, Achte koordinierte Bevölkerungsvorausberechnung, Variante 2, Wiesbaden 1994; Interministerielle Arbeitsgruppe, Bevölkerungsprognose, Variante A, Bonn 1996.
} 
Up to 1992 Germany had a pension system in which the pensions were linked $b$ the growth of gross wages. Based on this, the range of possibilities open to the politicians for 2035 is between doubling the contribution rates for the same pensions and halving the pensions with the same contribution rates. The politicians can choose some point within this range but they cannot perform miracles. If they are to succeed in preventing the contribution rate from increasing from $20 \%$ today to $40 \%$ in future, the pensioners must make sacrifices.

The Bundestag has defined a comprehensive program of sacrifices with its pension reforms of 1992 and 1997. It has replaced tying the pension to the gross wage with tying it to the net wage, it has done away with early retirement, it has abolished the pension for occupational invalidity (due to decline in earning capacity), it has made it more difficult to get a general disability pension, and it has decided that the pension of the so called "standard pensioner", that is, someone who has paid contributions based on average income for 45 years, will fall from $70 \%$ to $64 \%$ of the net wage. All these measures have helped make the problem seem less serious, but they only make up a policy of mere deficiency management which, whether intentionally or not, has obscured the issue of the coming crisis of the statutory pension insurance system. 
Figure 2: The development of the contribution rate with alternative population forecasts

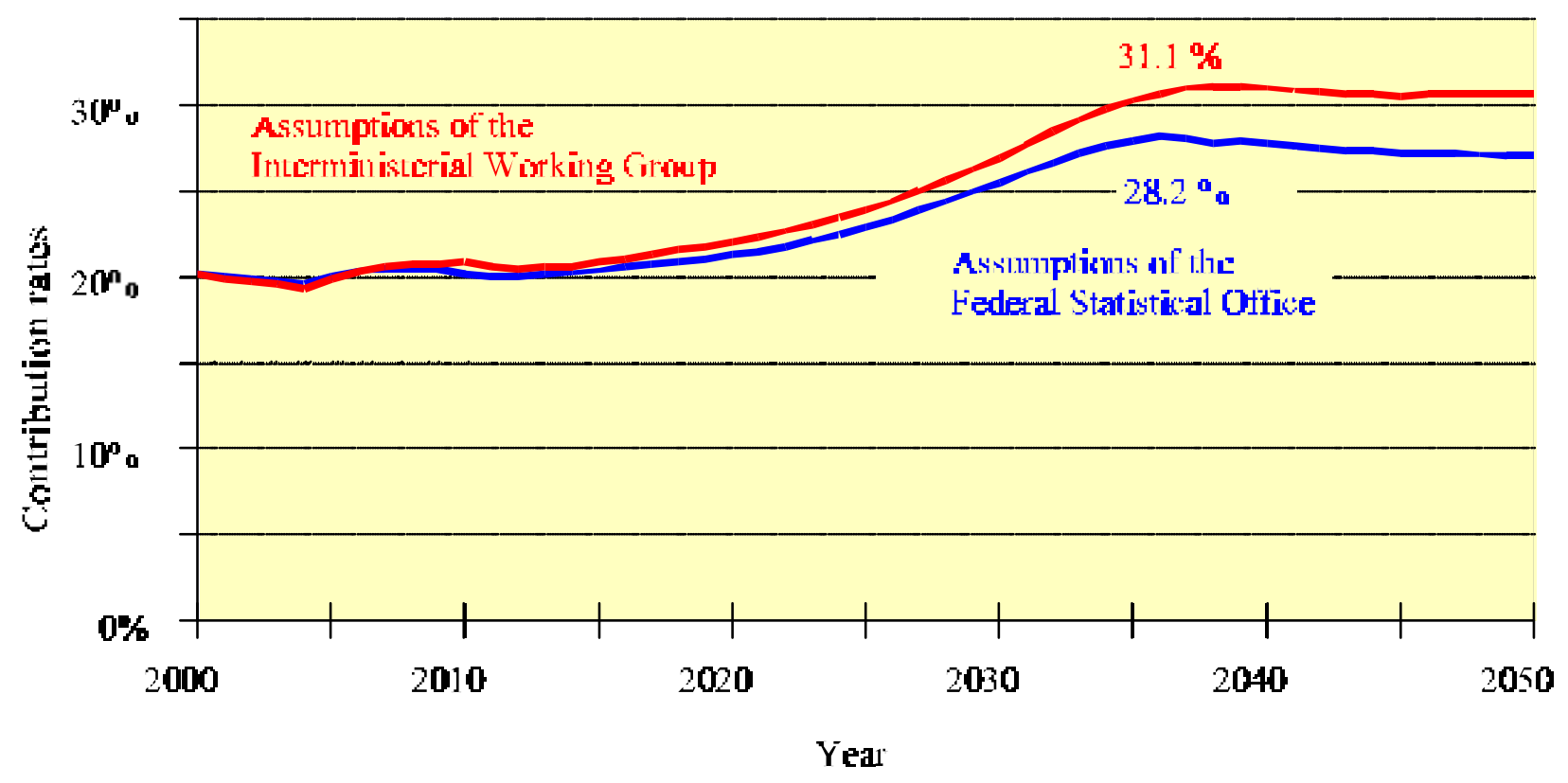

Source: $C E S$

Figure 2 illustrates the results of a model developed at $C E S$, using alternative population forecasts of the Federal Statistical Office and an Interministerial Working Group. ${ }^{6}$ The calculations cover the effects of the pension reductions which came into force in 1992 and 1997 and the increase in the federal grant established in 1997. The bottom forecast is based on the estimates of the Federal Statistical Office, which in turn were based on the optimistic - from the point of view of the pension insurance system - assumption that life expectancy of the west Germans will remain constant after the year 2000. It was also assumed that an additional 11 million foreigners will migrate to Germany up to the year 2030. The top forecast assumes an increase in life expectancy of 3 years and somewhat smaller immigration of 7 million people up to the year 2040 .

\footnotetext{
${ }^{6}$ See previous footnote.
} 
It can be seen that the contribution rate remains almost constant up to about the year 2020, increases rapidly after that, and by 2035 reaches its maximum value of between $28 \%$ to $31 \%^{7}$. Contribution rates of this order of magnitude will no longer be affordable and will lead to a revolt by the young against the old. In the light of this development, one can only have misgivings about the recent suggestion made by the Federal Ministry of Labor for lowering the retirement age to 60 . Realizing this suggestion would raise the contribution rate by a further 3 to 4 percentage points and put an even greater strain on the labor market. Even without this, Germany is at the start of an initially insidious, but increasingly alarming, crisis of the statutory pension insurance system, one which can have serious consequences for the state itself if suitable counter measures are not taken quickly.

\section{Pay-as-You-Go vs. Funding: Basic Remarks}

Germany could have looked at the coming demographic distortion quite composedly if its pension insurance system had been a fully capital funded system and not a contributory pay-asyou-go one, because the pensions could then have been financed by dispersing previous savings instead of by using the contributions of the working generation. With capital funding, the contributions to pension insurance are true savings which can be put on to the capital market and used to finance real investments. The stream of payments which the real investments produce can, if necessary, be used to pay back the loans to the savers and thus the pensions can be paid without putting a burden on the contributors. The only problem then is to create the capital stock. It is great if you have one, but the accumulation process is arduous.

After the pension insurance system had been established by Bismarck, it proved possible to build up, in only ten years, a capital stock that could have financed the pensions for seventeen

\footnotetext{
${ }^{7}$ An outline and commentary to alternative contribution forecasts is given in the Appendix to the text.
} 
years. Unfortunately the world wars and the inflation thwarted the plan and destroyed the system's capital base. Today the pension insurance system lives from hand to mouth. Its fund is only sufficient to cover it for 11 days.

Most Germans have no idea that the pension insurance system is a pay-as-you-go one. They think that the money that they pay into the pension insurance system today is in effect savings that they will be able to use later. This belief is, of course, mistaken, as the contributions are all used up in financing today's pensioners. Nothing, but nothing, is being saved. The supposed savings are just an illusion.

The illusion is encouraged by the equivalence between the contributions and the pensions, which is the characteristic feature of the German pension system. The person who pays in twice as much as his neighbor, later gets a pension which is about twice as large. One's contributions give a right to future pension payments and, to the contributor, this seems like paying into a savings account. The Federal Constitutional Court even has included the earned right to pension payments among the legal rights of ownership under Article 14 of the Basic Law.

In a pay-as-you-go system each generation when young pays its pension contributions to the old generation and acquires the right to receive pensions when it is old. These pensions are paid for by the next young generation's contributions. The first generation pays nothing for its pensions, each of the following generations must make payments to its preceding generation to acquire the right to its own pensions. These rights are a hidden implicit government debt, which, like an explicit government debt, must be paid for by the next generation. This implicit government debt is created when the first generation comes into the pension insurance system and it is turned over from generation to generation. Because the pensioners' rights are linked to wage developments, the size of the implicit government debt grows continuously over time, even when the population size is constant. 
Today the cash value of the rights already acquired, that is, the implicit government debt, is around DM 10 to 12 billion. That is more than Germany's total fixed assets and a multiple of the explicit government debt which comes to DM 2.2 billion. When the Euro came, the German debt-GDP ratio was just above the Maastricht limit of 60\%. If the implicit government debt of the pension insurance is added in, the total debt-GDP ratio becomes about $350 \%$.

The pay-as-you go system offers the contributors only a very modest return on the contributions they have paid in. Those who only had a few years left to contribute when the system was introduced in 1957 could pocket the initial profit and get a very high return to their contributions, one which was much higher than the returns in the capital market. But anyone who entered the scheme in 1957 or later made a worse deal than a capital market investment. Figure 3 shows the results of detailed calculations for this carried out at CES. The Figure shows the real inflation adjusted returns that the different age cohorts of sample male pensioners, who entered the pension insurance system after 1957, have received, or will receive in future, based on current estimates. The cohort of the sample pensioners entered the pension insurance system at age 20 . Some drew a normal age pension after 45 years of contributing to the system, others drew an early general disability pension, and still others died before they had received any pension. Some of the age cohorts left widows and orphans who also drew a pension. 
Figure 3: The internal returns to the statutory pension insurance system (SPI)

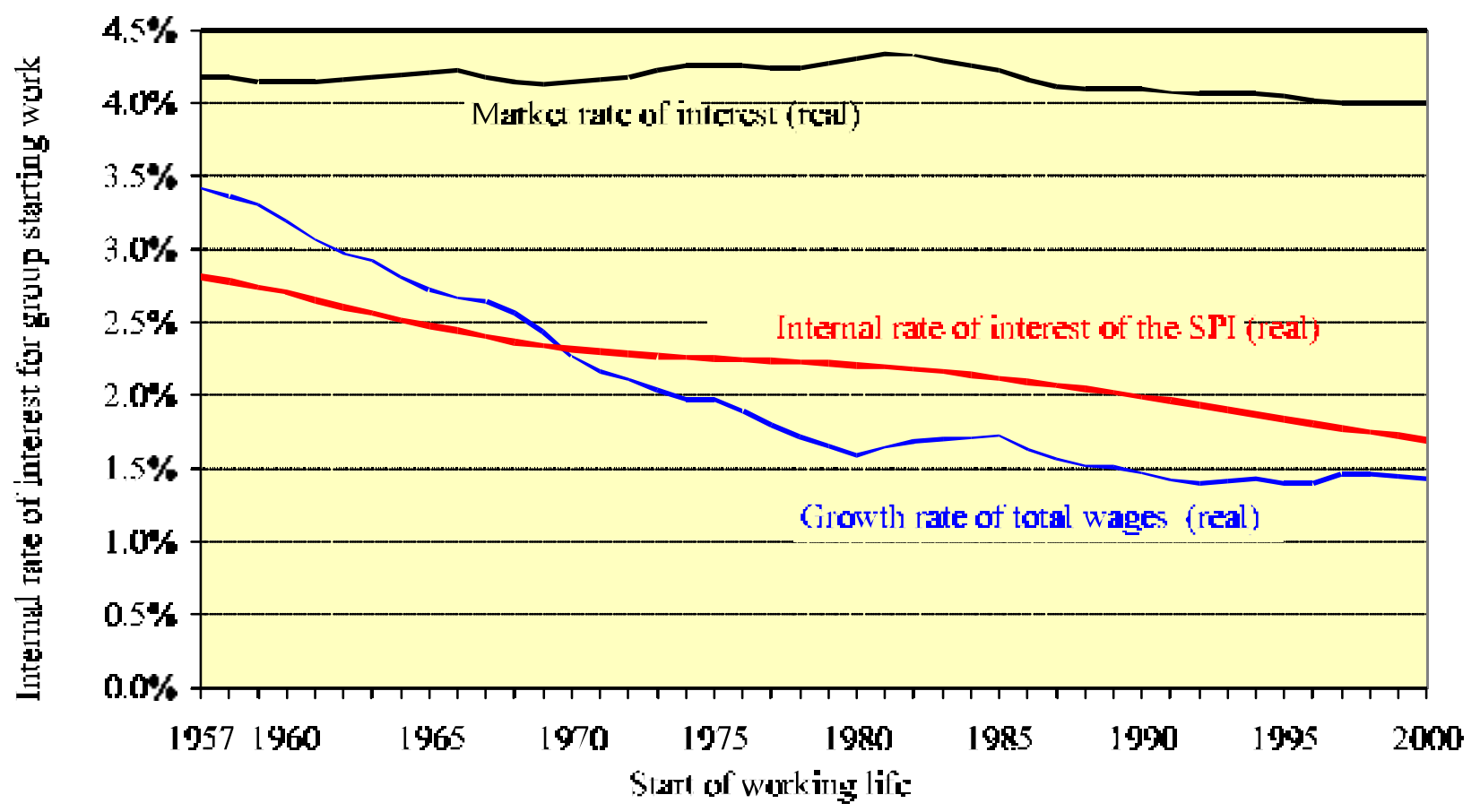

Source: $C E S$

It can be seen that the returns of the twenty year olds, who entered in 1957 and normally will become pensioners in 2002, are still almost $3 \%$. Those who entered as twenty year olds in 1990, however, can only expect a return on their contributions of $2 \%$, and the young people who enter now can only count on a real return of about $1.5 \%$. By contrast, savings invested in ten year federal bonds and rolled over for fifty years would, as the top curve shows, have brought a real interest rate of about $4 \%$.

It is not surprising that the returns to the pay-as-you -go system are so low. Theoretically, these returns are explained by the real growth rate of total wages. The figure shows that the theory comes pretty close to reality. The growth rate of total wages has, in fact, fallen greatly in the last forty years. If, as a result of the demographic distortion, it falls further, the returns that the pension insurance system can offer will also fall. 
At first sight, this data could be interpreted as a verdict on the German pension insurance system. In this interpretation the system appears to be a completely inefficient way of arranging old age provision; it should be abolished as quickly as possible and be replaced with a capital coverage system. Many observers have indeed interpreted the difference in returns in this way, and see it as a reason to introduce a capital coverage system.

This appearance deceives. To call the difference in returns "inefficient" is to make a grossly mistaken economic interpretation. The truth is that the difference in returns is an essential feature of the intergenerational redistribution. The difference in returns is an integral part of the pay-as-you-go system which one can no longer escape from once this system has been set up. It is the mirror image of the initial profit which accrued to the first post 1957 pension cohort; it has already been distributed and cannot be taken back again. Each subsequent generation has acquired a claim against the next generation by paying its pension contributions, but these claims are never high enough to keep pace with a capital market investment. It is as if each generation is paying an implicit tax to service the implicit government debt which resulted from the gift made to the first generation. The pension insurance system is a zero sum game being played by present and future generations in which the initial gain is mirrored by a loss of exactly the same amount for each subsequent generation when the present value of this amount is correctly calculated on an actuarial basis and when it is assumed that the discount rate and the interest rate at which funds can be invested are the same. ${ }^{8}$

Naturally, changing over to capital funding is attractive, if by doing so the implicit tax hidden in the contributions can be avoided. But this is impossible because the pension claims already established cannot simply be swept under the table. An explicit tax would be needed to service these claims and in present value terms this would be as just high as the implicit tax 
which all successive generations would have to pay if the pay-as-you-go system were to continue. Contrary to first appearances, it is not at all possible to exploit the returns advantage of the funded system in a way that results in a net advantage for society. The claim that the funded system is more efficient than the pay-as-you-go system because it brings higher returns is completely false from an economic point of view, as the higher returns only show up if the tax required to service past claims is disregarded.

\section{Resolving the Crisis by Partial Capital Funding}

All this does not mean that capital funding has no useful function. Quite the contrary, the statutory pension insurance system is in urgent need of help from capital funding, but it needs it for a different reason - not because it is inefficient. This reason is the demographic crisis that was described in the introduction. The problem is not about finding a system which promises more efficiency in the next century, it is about resolving the dangerous crisis which will affect the present thirty to forty year olds when they reach pension age.

If a generation is to survive in its old age without having to keep on working, it must make provision for it and there are, in principle, two ways of doing this. Either it can save and finance its keep by drawing on these savings, or it can have children so that these children will take care of it later. In harsh economic terms - people who want to have comfortable old age must have previously accumulated either real capital or „human capital“. Those who do not do one or the other must starve, because you get nothing for nothing.

In the past decades Germans have chosen not to accumulate as much „human capital“ as was usual in the past. This is the reason for the crisis. If they, nevertheless, still want to live comfortably in their old age, their only option is to substitute real capital for the missing ,human

\footnotetext{
${ }^{8}$ Feldstein (1998) emphasizes that this condition might not be satisfied and derives welfare gains from the difference
} 
capital“. The additional real capital secures some of the present nominal pension claims, and it prevents the subsequent generation having to carry an unjustified burden that is economically no longer affordable. It should be possible to cope with the pension burden, which would otherwise be crushing, by shouldering part of this burden now. This does not mean that changing over completely to a capital funding system would be necessary. Real capital must only be built up by the amount of the missing human capital. More than this is not required.

It is sometimes argued that the present employed generation cannot be expected to bear the burden of accumulating capital as well as the burden of their pension contributions. The transition to even partial capital accumulation, it is said, in itself implies an unfair double burden. This position fails to recognize that the employed generation must always bear a double burden since they must always maintain their own children as well as their parents. This was the case in the pre-industrial family, it is the case in today's world with government pension insurance, and it can never be otherwise. The pensions problem has arisen because the current employed generation has preferred to get rid of one of these burdens by having fewer children than was usual in the past. It is in no way unfair to ask this generation to put the money they save from not bringing up so many children into the capital market and to secure their pensions in this way. The necessary ability to pay is certainly there and there is no unfair second burden.

Of course a problem does arise here when it is considered that some families have enough children but other families have none. If those people, who are already financing the older generation with their pension contributions and who are also maintaining a sufficient number of children, are forced to save more, they will be faced with a third burden which can really be called unfair. A partial dependence of the pension on the number of children could help solve this 
problem, but this a matter of justice between families rather than generations which is not considered in this paper.

\section{Results of Simulation Calculations}

It is now time to be more specific. This section reports on the results of simulation calculations carried out at $C E S$ to discover the quantitative effects of alternative suggestions for reforms aimed at resolving the pensions crisis. The comparison refers to a complete transfer to capital funding, undermining the contribution mountain by setting up a fund within the statutory pension insurance system, and partial capital funding as in the alternative just discussed. The time path of the pension claims set out in the 1997 Pension Reform Law is taken as given for all the alternatives, so that only the developments of the burdens differ. Pensions for widows, orphans, and the unemployable will, in any case, continue to be financed by way of pay-as-you-go contributions. Capital funding will only be considered in relation to age pensions. The calculations are based on the relatively optimistic population estimates made by the Federal Statistical Office which were referred to in the beginning.

Figure 4 first shows the effects of an immediate transfer to full capital funding of age pensions. All claims already established are respected and continue to be financed through payas-you-go contributions. New claims, however, will be acquired entirely with capital accumulation from real savings. The upper path shown in the figure gives the sum of the pay-asyou-go contributions based on gross income and the savings contributions necessary to acquire claims the same as those with pay-as-you-go financing. For comparison purposes, the development of the contribution rate in the present pay-as-you-go system is again shown in the lower path. It can be seen that the initial burden in the case of complete transfer to capital funding is very high because the transition generation must pay twice - once for the other people's pensions which are based on already acquired claims and once for their own later pensions which 
are to be financed through savings. Only very gradually over the following decades does the payas-you-go financing of the claims already built up become less important and the total burden falls. Complete transfer will only occur around the year 2070 .

Figure 4: Contributions versus full capital funding

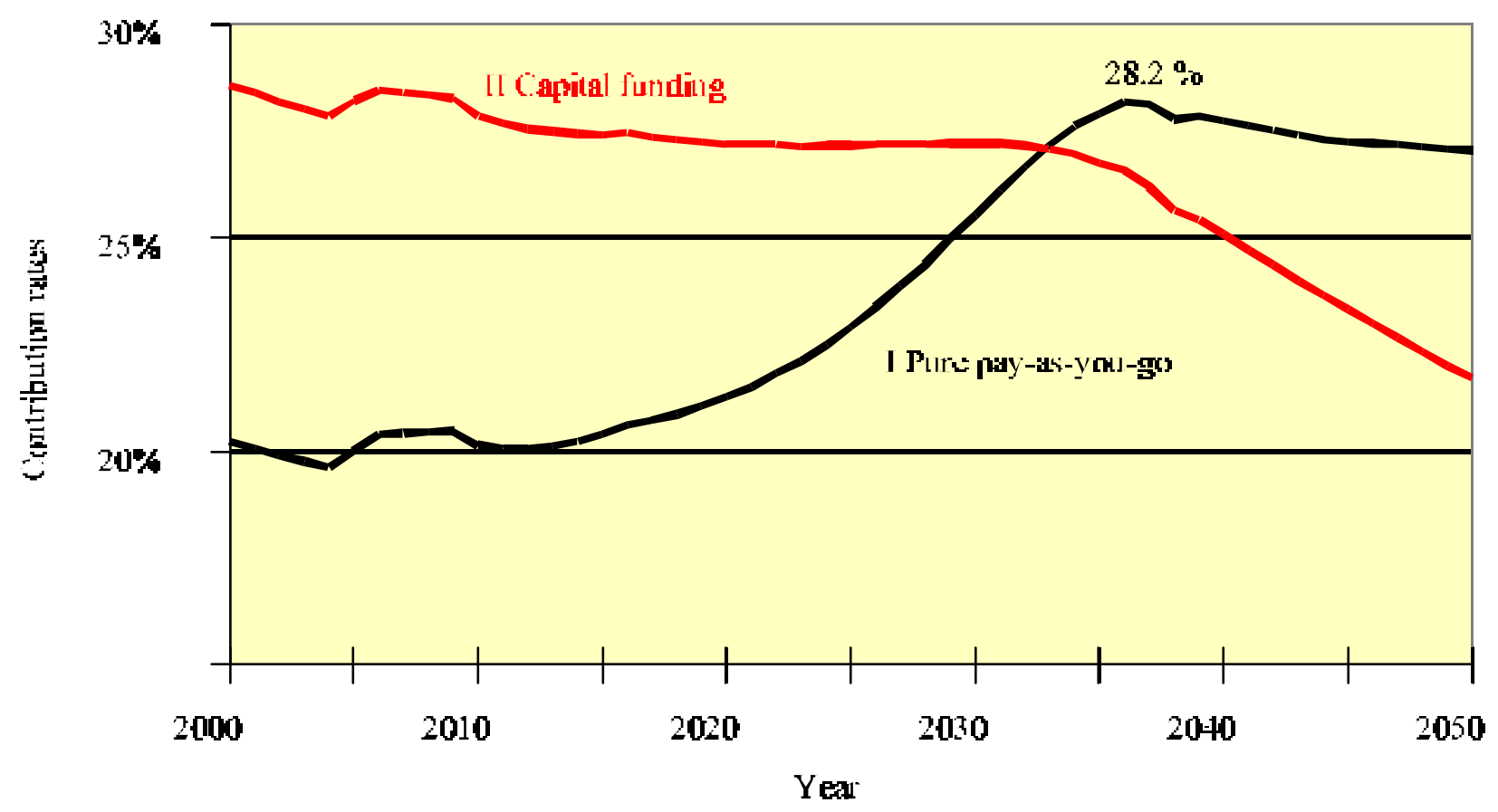

Source: $C E S$

It can be seen that the transfer to full capital funding takes the system out of the frying pan into the fire, because it is a mirror image of the pay-as-you-go path. The increase in charges to over $28 \%$ of gross wages, which under the present circumstances is to be expected in the fourth decade of the next century, starts immediately and so does the pensions crisis. Because the transfer to capital funding makes no comparable long term increase in efficiency possible, one can confidently reject this scenario. 
It would be ideal if there were a reform that would get rid of the impending crisis without a new burden turning up somewhere else, but this kind of reform could only occur in Lotus Land. In the real world, achieving an even distribution of the inevitable burden over time is expedient. In this way a confidence crisis in the pension insurance system, which at the same time would be a crisis of the state itself, could be averted.

One possibility to even out the burden over time is for the pension insurance system itself to accumulate the capital that could be used in the crisis years to contribute to financing the pensions. The pension contribution mountain would, so to speak, be undermined. Figure 5 shows this undermining. It can be seen that permanent stabilization would be possible if the contribution rate were to be raised immediately from the current $20 \%$ to $23.3 \%$ and kept at that level. In this way, the pension insurance system could accumulate a capital stock in the years up to about 2025 and this capital stock would then gradually be drawn down because the contribution rate would no longer be sufficient to finance the pensions. In this version, capital would only be accumulated in a transition phase. In the long run the pension insurance system's capital stock would once again be zero. 
Figure 5: Pay-as-you-go versus undermining

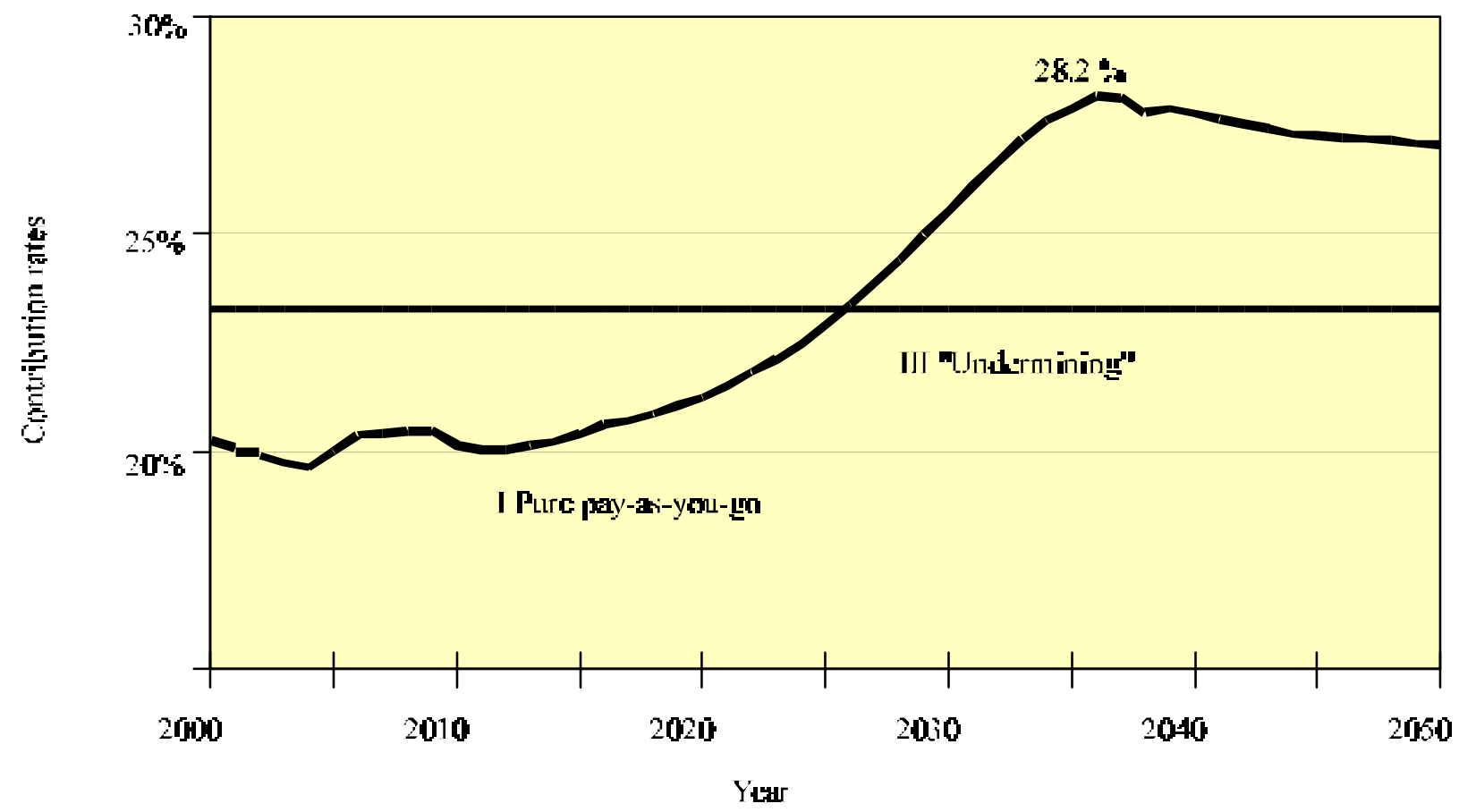

Source: $C E S$

Regardless of how attractive the undermining solution may appear at first sight, it fails to take into account the covetousness with which the politicians would look at a capital stock accumulated by the pension insurance system. It is hard to imagine a future federal Minister who wants to win the next election, resisting the pensioners' desire to use the capital stock prematurely. Public money is a great temptation.

Evening out the distribution must be brought about in another way, without the pension insurance system accumulating capital. One way which, after much discussion in the Scientific Advisory Council of the Federal Ministry of Economics and Research at CES, has come to be seen as practicable, is private partial capital funding with variable saving rates. Compulsory savings of initially about 4 to $4.5 \%$ of gross wages is to be arranged immediately. The people 
insured, themselves, would deposit these savings with recognized investment institutions and would inform the pension insurance system that they have done so. The compulsory savings will be varied over time in a way that keeps the sum of the pension contributions and savings contributions constant at about 24 to $24.5 \%$. The investment institutions compete with one another and their financial standing is strictly controlled by the regulatory authorities. The regulatory authorities report on the average pension returns from capital which accrue in this way to the relevant age groups. The pensions financed by contributions, and the contributions themselves, will be reduced by the amount of these returns.

Figure 6: Contributions versus partial capital funding

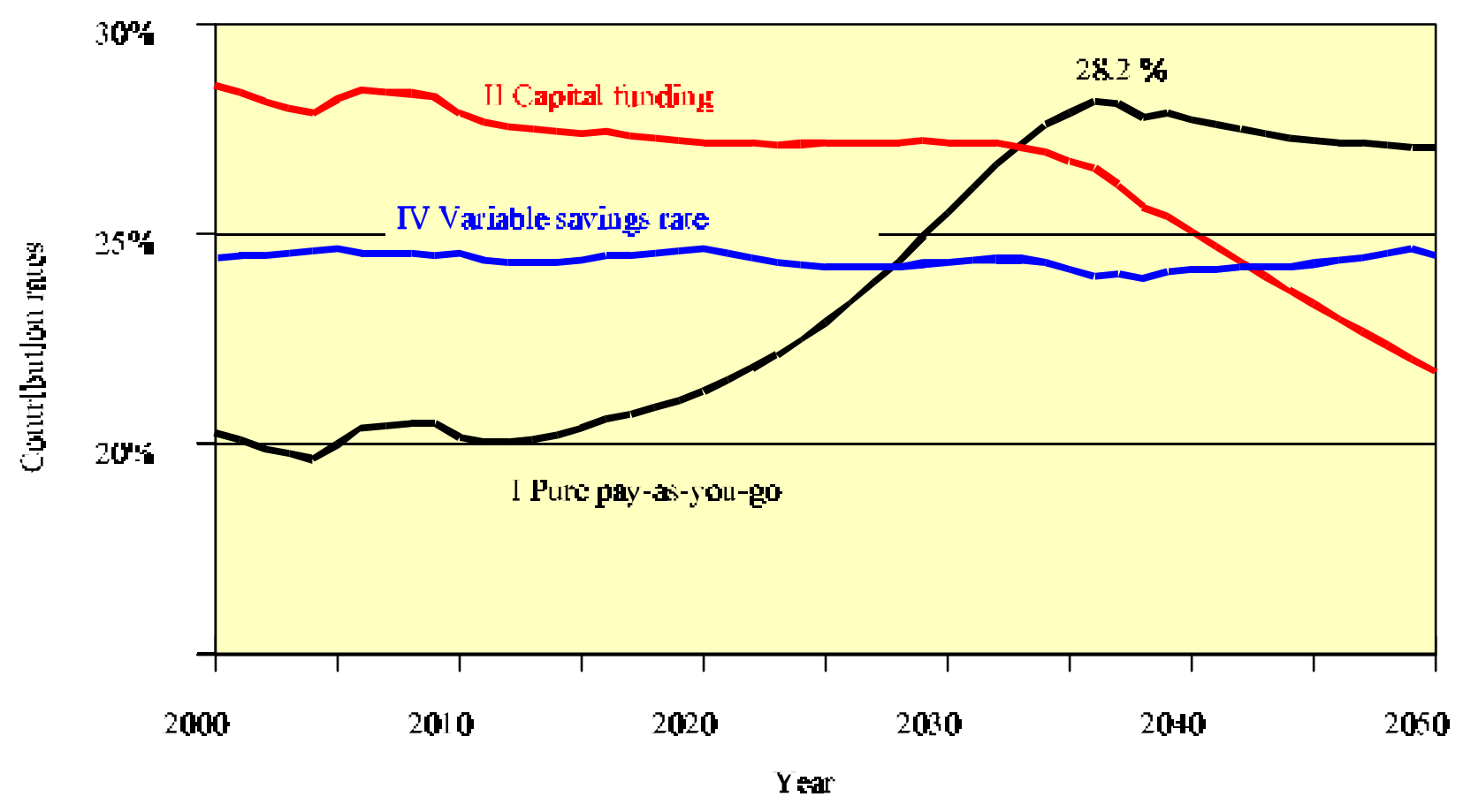

Source: $C E S$

The middle curve in Figure 6 shows the time path of the average contribution rates required for the savings and pension contributions. The two other curves show the already 
familiar paths of the burdens of the pay-as-you-go system and the transfer to a fully funded system. It can be seen that smoothing the path of the burden is in fact possible, and that the burden is permanently lower in the crisis years after 2028 than with the present system. At the peak of the crisis in 2035 , the contribution rate is more than three percentage points lower than the rate to be expected if the present pay-as-you-go method is retained. The burden is one percentage point higher than with the collective undermining solution, but, unlike that solution, it permanently accumulates capital. Up to the peak of the crisis, a quarter of the age pensions can be financed from savings and, in the long run, half capital funding will be achieved. In the very long term - in the last quarter of the next century - the burden will fall below that associated with the undermining solution. The transfer to partial capital funding is then complete.

In the following Figure 7 it can be seen how the smoothing of the path of the burden comes about through varying its components. The upper curve shows the total expenditures whose path is already known from the previous figure. The curve below this shows as before the necessary pay-as-you-go contributions. The curve begins with the present value of $20 \%$, then rises only very slowly because more and more capital funded pension components are available. At the peak of the demographic crisis a contribution burden of only $22 \%$ will be reached, which is much lower than the $28 \%$ which must be expected with the present system. The lower curve shows the path of the compulsory savings rate which, together with the pay-as-you-go contributions, makes up the total expenditures.

Up to about 2020 the compulsory savings rate is over $4 \%$, it falls to only $1 \%$ up to 2036 when it again rises gradually. This variability in the compulsory savings rate is what determines the smoothing of the path of the total burden. 
Figure 7: The path of the savings rate

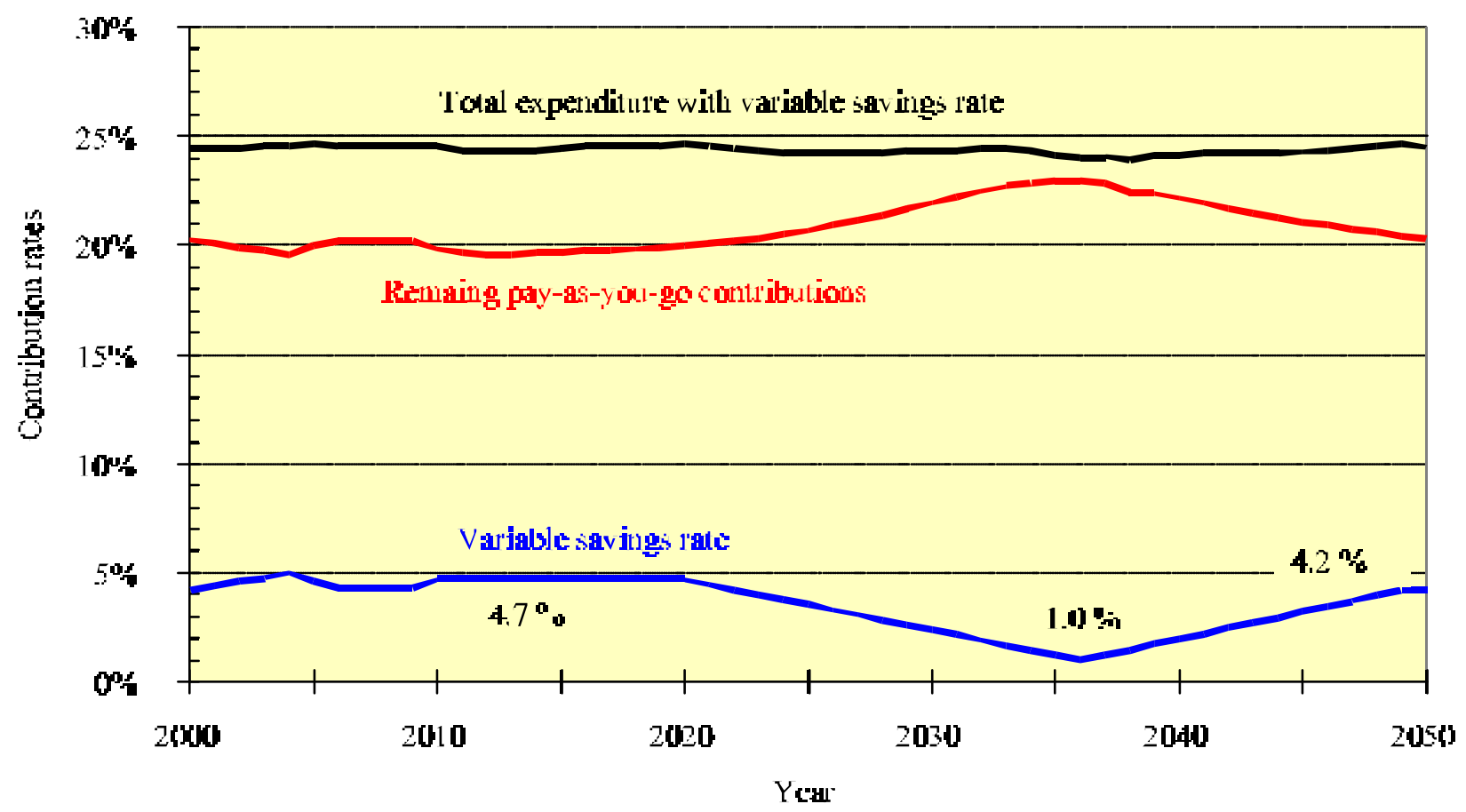

Source: $C E S$

In the next twenty years the national income related savings in this solution are between 3 and 4 percent. This is not too much and not too little. Some critics of capital funding maintain that the capital market cannot absorb more capital from savings and others maintain that savings are irrelevant because national expenditure can only be financed from the national product of the current period. This is not the place to explain why these statements are misleading, if not completely wrong. But one thing is certain. Germany's savings rate today of around $9 \%$ is well below the $15 \%$ which brought Germany prosperity and growth in the sixties. It could only be to the economy's benefit if the savings rate were to rise by 3 to 4 percentage points as a result of capital funding the pension insurance. One would not have reached the savings rate of the sixties but one would be getting closer to it. An increase in savings produces an increase in national 
product, and that increase in national product will make future national expenditure easier to afford than it otherwise would have been.

\section{Concluding Remarks}

It has been shown that the German pension insurance system is sliding into a demographic crisis and that partial capital funding on a private basis, but under government supervision, is a way to avoid a disaster. Compared to this, Germany's present policy of mere deficiency management is no solution at all.

Germany's crisis can be averted by capital funding without reducing the level of pensions even further than the 1992 and 1997 reforms already have. Partial capital funding is the golden mean between the extremes of pure pay-as-you-go financing and pure capital funding. It unites the strengths of both the systems and, last but not least, is an insurance strategy with respect to the idiosyncratic risks involved with both alternatives.

Bismarck wanted to prevent the old and the sick from being "pushed aside" by the young. The reform presented in this paper will prevent the pension insurance system from one day being pushed aside by the young and, with it, perhaps the state itself, too. 


\section{Appendix: Comments on alternative contributions forecasts}

The forecast shown in Figure 2 is a conditional estimate in which the conditions are assumptions which do not have to be accepted. Other results follow from other assumptions. Figure 8 gives an overview of alternative forecasts which have been made recently in different places. It can be seen that the range of the forecasts of the contribution rate for the year 2030 is between about $25 \%$ and $31 \%$. The third curve from below shows the lower of the forecasts made at the Center for Economic Studies (CES), which have also been used by the Scientific Advisory Council of the Federal Ministry of Economics and Research and on which this paper is based.

Figure 8: Alternative forecasts of the development of the contributions rate

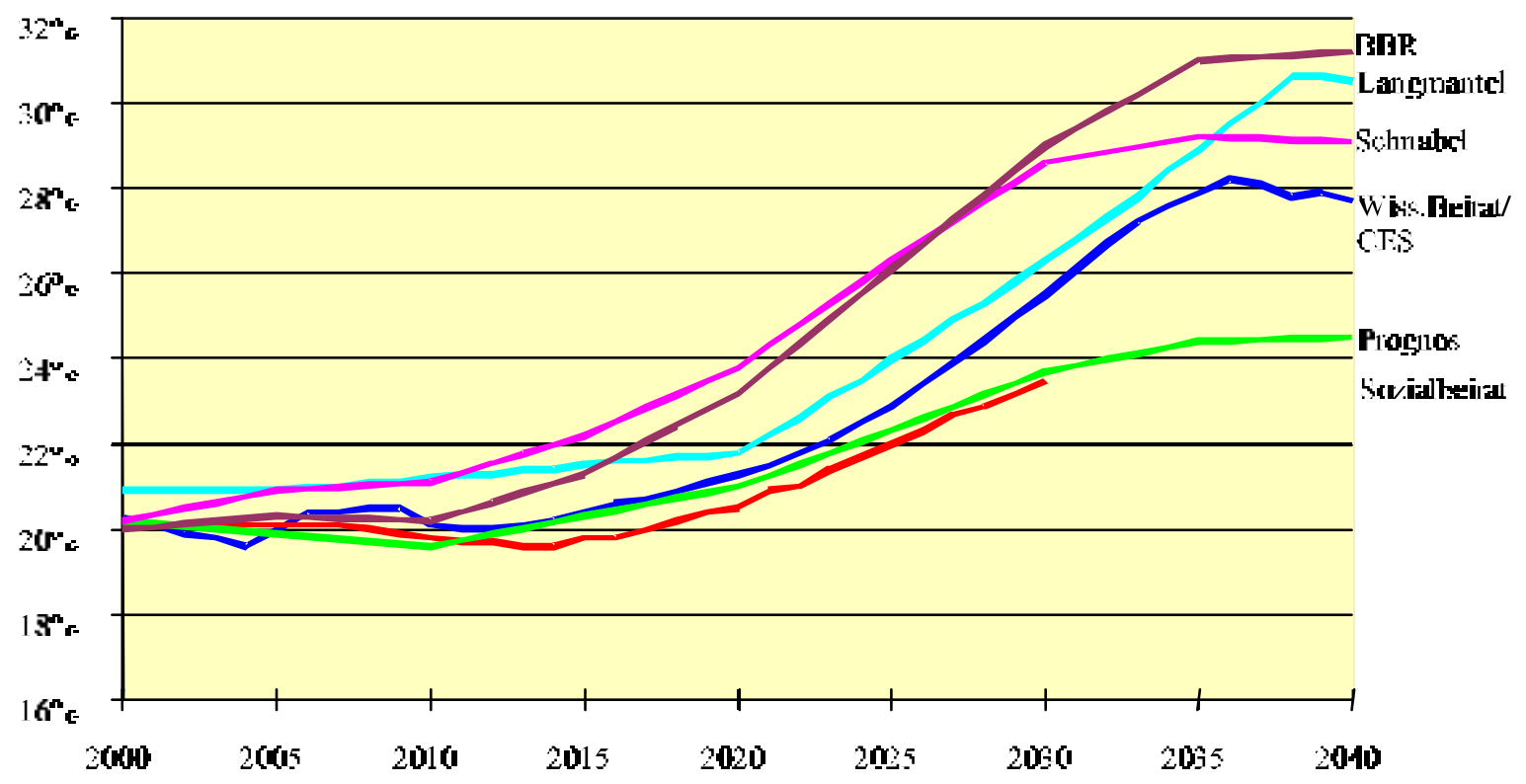

Sources: Sozialbeirat (1998); Prognos (1998); Wissenschaftlicher Beirat beim Bundesministerium für Wirtschaft (1998); Schnabel (1998); Langmantel (1997); Besendorfer, Borgmann and Raffelhüschen (BBR, 1998). 
A look at the other forecasts permits to see how sensitive the calculations are to alternative assumptions. It is noteworthy how low the estimates of the contribution rates made by Prognos-AG for the Federal Ministry of Labor and the Federal Association of Pension Insurance Institutions are ${ }^{9}$. One third of the difference between this and the $C E S$ forecast $(1.25$ percentage points) stems from the fact that the Prognos-AG assumes increases in the federal grant over and above that determined in 1997, and two thirds (2.45 percentage points) from the fact that it assumes a large increase in other, differently based, rates of taxes and charges on wage incomes. The higher the other charges, the lower the pension claims implied by the German pension formula, and the lower the resulting contributions burden. Prognos implicitly assumes that the total burden on wage incomes from income tax and charges for pension, health, unemployment, and nursing insurance will be an alarming 70\%, while the CES forecast implicitly assumes a total burden of $66 \%$. Here, the tax needed to finance the increased federal grants, which Prognos really must impute, is not even included. Reduced to a single denominator, the pension burden indicated by Prognos is relatively low because both the other burdens and the total burden on employees are assumed to be relatively high. Looking at the Prognos calculations as a whole, the arguments in favor of partial capital funding are considerably stronger than with the CES forecast. While politicians have read an all clear signal for the pension problem from the Prognos forecast, this indicates that the calculations published by Prognos have been grossly misinterpreted.

The $C E S$ forecast is a status quo prediction. It assumes a constant rate for charges for other purposes, because it wants to isolate the effect of the demographic distortion on the pension contributions. There will be several more tax reforms and changes in the pattern of other charges by the time the peak of the crisis arrives. One of these is the tax reform already decided on by the

\footnotetext{
9 The difference between the CES forecast and that of the Prognos-AG were worked out by Marcel Thum for a lecture given at the Akademie für politische Bildung in Tutzing on 16.11.1998. A useful comparison of the alternative forecasts can be found in Werding (1998).
} 
new Federal Government which Prognos has not taken into account. In view of this political uncertainty, it makes little sense to carry out the calculations on the basis of the current income tax progression scale. The pension reduction that will be produced through this mechanism as a result of adjustment of net wages is an artifact which will certainly not reflect the reality of the next four decades.

The CES forecast used in this paper is the more cautious of the two alternative forecasts because it assumes a large immigration (11 million) and no further increase in life expectancy in West Germany. Only the East German life expectancy is assumed to increase until it reaches the West German level. If it is assumed, as the Interministerial Working Group does (cf. figure 2), that there will be a further increase in life expectancy of three years and a smaller immigration (7 million) then the CES forecast, too, largely coincides with the top three forecasts shown in the figure. 


\section{List of References}

Besendorfer, D., C. Borgmann and B. Raffelhüschen (1998), Ein Plädoyer für intergenerative Ausgewogenheit: Rentenreformvorschläge auf dem Prüfstand, Discussion Paper 65/98, Universität Freiburg.

Feldstein, M. (1998), Privatizing social security: A National Bureau of Economics Research project report, Univ. of Chicago Press.

Interministerielle Arbeitsgruppe (1996), Bevölkerungsprognose, Variante A, Bonn.

Kaiserliches Statisches Amt (1878), Statistisches Jahrbuch für das Deutsche Reich, Vol. 30.

Langmantel, E. et al. (1997), Entlastungspotential eines Teilkapitalstocks unter alternativen Bevölkerungsannahmen, ifo: München.

Mitchell, B.R. (1981), European Historical Statistics:1750-1975, $2^{\text {nd }}$ revision, Facts on File: New York, NY.

Prognos (1998), Auswirkungen veränderter ökonomischer und rechtlicher Rahmenbedingungen auf die gesetzliche Rentenversicherung in Deutschland, DRV-Schriften, Vol. 9: Frankfurt am Main.

Schnabel, R. (1998), Rates of Return of the German Pay-As-You-Go Pension System, Working Paper, Universität Mannheim.

Sinn, H.-W. (1997), The Value of Children and Immigrants in a Pay-As-You-Go Pension System: A Proposal for a Partial Transition to a Funded System, NBER Working Paper No. 6229, Cambridge, MA.

Sinn, H.-W. (1998a), The Pay-as-you-go Pension System as a Fertility Insurance and Enforcement Device, CES Discussion Paper No. 154, Universität München.

Sinn, H-W. (1998b), "Comment on Axel Börsch Supan", H. Siebert, ed., Redesigning Social Security, Mohr-Siebeck: Tübingen, 197-203.

Sozialbeirat (1998), Gutachten des Sozialbeirats zum Rentenversicherungsbericht 1998 und Stellungnahmen zu einigen weiteren Berichten zur Alterssicherung.

Statistisches Bundesamt (1994), Achte koordinierte Bevölkerungsvorausberechnung, Variante 2, Wiesbaden.

Stein, P. (no year), Fürst Bismarcks Reden, Achter Band: Steuerreform und Socialpolitik 18801882, Reclam: Leipzig, p. 174.

Werding, M. (1998), "Humankapitalbildung, Beschäftigung und Altersvorsorge", forthcoming in: Beiträge zur Arbeitsmarkt- und Berufsforschung, IAB: Nürnberg.

Wissenschaftlicher Beirat beim Bundesministerium für Wirtschaft (1998), Grundlegende Reform der gesetzlichen Rentenversicherung, Bundesministerium für Wirtschaft: Bonn. 